\title{
Comunicação
}

[Communication]

\section{Levantamento sorológico de Mycobacterium avium subesp. paratuberculosis em bovinos leiteiros no estado do Espírito Santo}

\author{
[Serological survey of Mycobacterium avium subsp. paratuberculosis in dairy cattle in Espírito Santo state] \\ J.C.M. Costa $^{1}$, F.A. Pieri ${ }^{1}$, C.F. Souza ${ }^{1}$, I.F. Espeschit ${ }^{1}$, A.G. Felippe ${ }^{1}$, G.M. Santos ${ }^{2}$, \\ F.L. Tobia ${ }^{1}$, A. Silva Junior ${ }^{1}$, M.A.S. Moreira ${ }^{1 *}$ \\ ${ }^{1}$ Universidade Federal de Viçosa \\ Rua P.H. Rolfs, $\mathrm{s} / \mathrm{n}$, \\ 36570-000 - Viçosa, MG \\ ${ }^{2}$ Centro Universitário de Vila Velha - Vila Velha, ES
}

A paratuberculose, ou Doença de Johne, é uma enterite infecciosa crônica causada pelo Mycobacterium avium subesp. paratuberculosis (MAP), que acomete todos os ruminantes. Apresenta uma forma clínica, quando se observam enterite crônica, perda de peso e fraqueza que, geralmente, levam o animal a óbito, e, ainda, uma forma subclínica, quando não há nenhum sinal da doença. No entanto, há eliminação do agente no ambiente tornando-se uma fonte de risco ao rebanho ou aos animais próximos (Radostitis, 2000). Sob condições naturais, geralmente a transmissão ocorre pela ingestão de alimento ou de água contaminada com MAP, embora também possa ocorrer por meio da infecção intrauterina, do colostro de fêmeas infectadas ou de sêmen contaminado (Radostitis, 2000).

A paratuberculose pertence às enfermidades da Organização Mundial da Saúde Animal (OIE), que compreendem as doenças transmissíveis de importância socioeconômica e/ou de importância em saúde pública, cujo controle é necessário para o comércio internacional de animais e alimentos de origem animal (World..., 2010). A relevância da paratuberculose em se tratando de saúde pública deve-se ao seu possível potencial zoonótico na doença de Crohn em pacientes humanos (Waddel et al., 2008). Nesse caso, o principal veículo para a transmissão do microrganismo seria o leite cru e, possivelmente, o leite pasteurizado, uma vez que estudos demonstraram a presença de células viáveis (Waddel et al., 2008).

A paratuberculose é de importância mundial, visto que proporciona prejuízo econômico, principalmente nos rebanhos leiteiros, por aumentar os custos sanitários devido à cronicidade da enfermidade. Em alguns países, a doença gera perdas de, aproximadamente, US\$100,00 por vaca, além de redução de 700kg de leite por vaca (Stephen et al., 1999). A cultura fecal é o método considerado "padrão-ouro" para o diagnóstico da doença, entretanto, em função da natureza fastidiosa do agente e de seu crescimento muito lento, o cultivo constitui um procedimento demorado e oneroso (Buergelt e Ginn, 2000). Atualmente, o ensaio imunoenzimático (ELISA) está sendo usado como o teste de eleição devido à sua praticidade e a seu baixo custo, o que proporciona a realização de exame de um grande número de amostras (Acypreste et al., 2005), bem como apresenta um papel significativo nos programas de controle internacional. Além disso, o ELISA indireto possui alta sensibilidade e especificidade e tem a capacidade de identificar animais soropositivos ainda assintomáticos, facilitando o controle da propagação da doença no rebanho (Roussel et al., 2007).

Recebido em 3 de março de 2010

Aceito em 19 de novembro de 2010

*Autor para correspondência (corresponding author)

E-mail:masm@ufv.br 
No Brasil, a preocupação com a doença ainda é discreta, com poucas publicações científicas (Carvalho et al., 2009). O estado do Espírito Santo não possui estudo a respeito da presença do MAP em seu território, o que constitui um risco para a pecuária leiteira local e para os estados limítrofes. Tendo em vista a escassez de estudos e a importância que o MAP possui sobre o setor lácteo, este trabalho teve como objetivo verificar a ocorrência de anticorpos anti-MAP em bovinos leiteiros no estado do Espírito Santo, utilizando-se o teste do ELISA indireto.

Foram coletadas 1450 amostras de soro sanguíneo de bovinos leiteiros, em amostragem não probabilística, provenientes de 24 rebanhos das quatro mesorregiões do estado. As amostras coletadas foram mantidas a $-20^{\circ} \mathrm{C}$ até o momento das análises, e o ELISA para a detecção dos anticorpos anti-MAP foi realizado com o kit ELISA Paratuberculosis Antibodies Screening (Institut Pourquier - Montpellier, França). As análises foram realizadas no Laboratório de Doenças Bacterianas do Departamento de Veterinária da Universidade Federal de Viçosa. O procedimento do teste seguiu-se de acordo com o protocolo fornecido pelo fabricante, em placas de microtitulação de 96 orifícios, previamente sensibilizadas com o antígeno do MAP. Para a leitura das placas, foi utilizado um espectrofotômetro (Bio-Tec Instruments Inc. Winooski, EUA) com comprimento de onda de 450nm (OD450). A razão amostra/controle positivo (S/P) apresentada abaixo foi utilizada para a interpretação dos resultados.

$$
\begin{aligned}
& \mathrm{S} / \mathrm{P}=\underline{100 \times \text { (valor da } \mathrm{OD}_{450} \text { da amostra }- \text { valor da } \mathrm{OD}_{450} \text { do controle negativo) }} \\
& \text { (valor da } \mathrm{OD}_{450} \text { do controle positivo - valor da } \mathrm{OD}_{450} \text { do controle negativo) }
\end{aligned}
$$

Os testes foram realizados em triplicata e, para cada amostra, o valor da $\mathrm{OD}_{450}$ utilizada foi o valor da $\mathrm{OD}_{450}$ médio obtido das três reações. $\mathrm{O}$ ponto de corte para amostras consideradas negativas para anticorpos anti-MAP atendeu a valores $\mathrm{S} / \mathrm{P}$ iguais ou menores que $60 \%$; para amostras consideradas suspeitas, o ponto de corte figurou entre $60 \%$ e $70 \%$; e valores $\mathrm{S} / \mathrm{P}$ iguais ou maiores que $70 \%$ foram considerados como resultados positivos, seguindo recomendações do fabricante. Os resultados foram considerados somente se a razão entre a $\mathrm{OD}_{450}$ do controle positivo e a $\mathrm{OD}_{450}$ do controle negativo foi maior ou igual a 3.

Os resultados estão apresentados na Tab. 1. Dentre as 1450 amostras, 165 (11.4\%) apresentaram anticorpos anti-MAP, 33 amostras (2,3\%) foram suspeitas e 1252 amostras foram negativas, representando 86,4\% de animais não reagentes. Observou-se também que, na mesorregião Sul Espírito-Santense, foi encontrado o maior índice de animais soropositivos, representando 20,9\%, e na mesorregião Central Espírito-Santense, o menor índice, 4,7\%. As mesorregiões Noroeste e Litoral Norte Espírito-Santense aprentaram 11,2\% e $6,5 \%$ de animais soropositivos, respectivamente. Em relação aos rebanhos estudados, 6-Mimoso do Sul, localizado na mesorregião Sul, apresentou o maior índice de soropositivos entre os rebanhos (53,6\%), e os rebanhos 5-Colatina, localizado na mesorregião Noroeste, 1-Montanha e 2-João Neiva, localizados na mesorregião Litoral Norte Espírito-Santense, não tiveram animais soropositivos. Foi demonstrado que todas as mesorregiões estudadas apresentaram animais soropositivos, no total de 11,2\%. Nenhum dos animais avaliados apresentava sinais clínicos sugestivos da doença no momento da coleta, demonstrando a eficácia do ELISA indireto na detecção de animais soropositivos, mesmo sem apresentar sintomatologia. Os diferentes resultados encontrados por mesorregiões podem ser atribuídos a diferentes fatores como tipo de criação, manejo sanitário ou mesmo o clima de cada mesorregião estudada. Embora a paratuberculose exista no Brasil, a presença de MAP nos rebanhos bovinos leiteiros de muitos estados brasileiros, como o Espírito Santo, ainda é desconhecida. Os resultados encontrados comprovam a presença do MAP em todas as mesorregiões estudadas, representando um grande risco ao setor lácteo do Espírito Santo e também às bacias leiteiras dos estados limítrofes, como Minas Gerais, o maior produtor de leite do país. Além disso, devido à sua possível associação com a doença de Crohn, implica também um possível risco à saúde da população, tendo em vista que o MAP pode ser transmitido pelo consumo de leite cru e, possivelmente, de leite pasteurizado (HermonTaylor, 2001). Em razão da importância socioeconômica e em saúde pública do MAP, espera-se que os resultados obtidos alertem as 
autoridades sanitárias competentes e contribuam para a implementação de medidas de controle e prevenção da doença no estado ou mesmo no país. Verificou-se que o agente encontra-se difundido no estado, sendo este trabalho o primeiro relato de MAP em bovinos leiteiros no estado do Espírito Santo.

Tabela 1. Resultados do ELISA indireto para identificação de anticorpos anti- Mycobacterium avium subesp. paratuberculosis de acordo com cada mesorregião do estado do Espírito Santo, 2009

\begin{tabular}{|c|c|c|c|c|c|c|c|}
\hline \multirow{2}{*}{ Mesorregião } & \multirow{2}{*}{ Rebanho } & \multicolumn{3}{|c|}{ Soro } & \multicolumn{2}{|c|}{ Total de soro } & \multirow{2}{*}{$\%$} \\
\hline & & $(+)$ & $(-)$ & Suspeitos & Rebanho & Mesorregião & \\
\hline \multirow{5}{*}{$\begin{array}{l}\text { Mesorregião } \\
\text { Central } \\
\text { Espírito- } \\
\text { Santense }\end{array}$} & 1-Cariacica & 5 & 130 & 1 & 136 & \multirow{5}{*}{254} & \multirow{5}{*}{17,5} \\
\hline & 2-Guarapari & 5 & 39 & 1 & 45 & & \\
\hline & 3-Conceição do & 0 & 39 & 0 & 39 & & \\
\hline & 4-Itapemirim & 1 & 13 & 1 & 15 & & \\
\hline & 5-Marataízes & 1 & 18 & 0 & 19 & & \\
\hline Mesorregião & 1-Montanha & 0 & 59 & 0 & 59 & \multirow{6}{*}{262} & \multirow{6}{*}{18,1} \\
\hline Litoral Norte & 2-João Neiva & 0 & 10 & 0 & 10 & & \\
\hline Espírito- & 3-Mucurici & 2 & 76 & 0 & 78 & & \\
\hline \multirow{3}{*}{ Santense } & 4-Pedro Canário & 13 & 62 & 3 & 78 & & \\
\hline & 5-Pinheiro & 2 & 34 & 1 & 37 & & \\
\hline & 1-Ecoporanga & 8 & 55 & 1 & 64 & & \\
\hline \multirow{4}{*}{$\begin{array}{l}\text { Mesorregião } \\
\text { Noroeste } \\
\text { Espírito- } \\
\text { Santense }\end{array}$} & 2-Boa Esperança & 3 & 66 & 3 & 72 & \multirow{5}{*}{609} & \multirow{5}{*}{42,0} \\
\hline & 3-Nova Venécia & 3 & 62 & 0 & 65 & & \\
\hline & 4-São Gabriel da & 4 & & 1 & 33 & & \\
\hline & $\begin{array}{l}\text { Palha } \\
\text { 5-Colatina }\end{array}$ & 45 & $\begin{array}{c}28 \\
295\end{array}$ & 7 & 347 & & \\
\hline \multirow{8}{*}{$\begin{array}{l}\text { Mesorregião } \\
\text { Sul Espírito- } \\
\text { Santense }\end{array}$} & 6-Baixo Guandu & 5 & 21 & 2 & 28 & & \\
\hline & 1-Alegre & 8 & 93 & 3 & 104 & \multirow{7}{*}{325} & \multirow{7}{*}{22,4} \\
\hline & 2-Guaçuí & 3 & 30 & 3 & 36 & & \\
\hline & $\begin{array}{l}\text { 3-Jerônimo } \\
\text { Monteiro }\end{array}$ & 15 & 33 & 1 & 49 & & \\
\hline & $\begin{array}{l}\text { 4-Cach. do } \\
\text { Itapemirim }\end{array}$ & 1 & 37 & 0 & 38 & & \\
\hline & $\begin{array}{l}\text { 5-Rio Novo do } \\
\text { Sul }\end{array}$ & 9 & 0 & 0 & 9 & & \\
\hline & 6-Mimoso do Sul & 30 & 22 & 4 & 56 & & \\
\hline & $\begin{array}{l}\text { 7-Presidente } \\
\text { Kennedy }\end{array}$ & 2 & 30 & 1 & 33 & & \\
\hline Total & 24 & 165 & 1252 & 33 & 1450 & 1450 & 100 \\
\hline
\end{tabular}

Palavras-chave: bovino, ELISA, anticorpos, ocorrência

\section{ABSTRACT}

The occurrence of antibodies to Mycobacterium avium subsp. paratuberculosis (MAP) was verified in dairy cattle from Espírito Santo state. A total of 1,450 serum samples were analyzed for antibodies antiMAP, using ELISA. Dairy cattle, males and females, from four regions of Espírito Santo state were used. One hundred sixty-five (11.4\%) samples were positive for anti-MAP, 33 (2.3\%) were considered suspicious, and 1,252 (86.3\%) were negative. In all regions, seropositive animals were found, indicating that the agent is spread by the State, posing a threat to the local dairy farming and neighboring states, as well as public health, since MAP can be involved with Crohn's disease in humans. This result presents the first serologic anti-MAP survey in dairy cattle of Espírito Santo State.

Keywords: cattle, ELISA, antibody, occurrence 


\section{AGRADECIMENTOS}

Os autores agradecem à FAPEMIG, à CAPES e ao CNPq, pelo suporte financeiro.

\section{REFERÊNCIAS BIBLIOGRÁFICAS}

ACYPRESTE, C.S.; JULIANO, R.S.; RIVEIRA, F.E.B. et al. Uso da técnica do ELISA indireto na detecção de anticorpos anti-Mycobacterium paratuberculosis em vacas em lactação. Cienc. Anim. Bras., v.6, p.41-45, 2005.

BUERGELT, C.D.; GINN, P.E. The histopathologic diagnosis of subclinical Johne's disease in North American Bison (Bison bison). Vet. Microbiol., v.77, p.325-331, 2000.

CARVALHO, I.A.; SILVA, A.; CAMPOS, V.E.B. et al. Detection of Mycobacterium avium subspecies paratuberculosis by polymerase chain reaction in bovine milk in Brazil. J. Dairy Sci., v.92, p.5408-5410, 2009.

HERMON-TAYLOR, J. Protagonist. Mycobacterium avium subspecies paratuberculosis is a cause of Crohn's disease. Gut, v.49, p.755-756, 2001.
RADOSTITS, O.M., SAY, C.C.; BLOOD, D.C. et al. Clínica veterinária. 9.ed. Rio de Janeiro: Guanabara Koogan, 2000. p.1118-1119.

ROUSSEL, A.J.; FOSGATE, G.T.; MANNING, E.J.B. et al. Association of fecal shedding of mycobacteria with high ELISA-determined seroprevalence for paratuberculosis in beef herds. J. Am. Vet. Med. Assoc., v.230, p.890-895, 2007.

STEPHEN, L.O.; SCOTT, J.W.; BRUCE, A.W. Herd-level economic losses associated with Johne's disease on US dairy operations. Prev. Vet. Med., v.40, p.179-192, 1999.

WADDELL, L.A.; RAJIĆ, A.; SARGEANT, J. et al. The zoonotic potential of Mycobacterium avium ssp. paratuberculosis: a systematic review. Can. J. Public. Health, v.99, p.145-155, 2008.

WORLD ORGANIZATION FOR ANIMAL HEALTH. OIE, Listed diseases, 2010. Disponível em:

$<$ http://www.oie.int/eng/maladies/en_classificati on2007.htm\#ListeOIE/>. Acessado em 15 out. 2010. 